\title{
Internationalisation of research and development activities of small and medium-sized enterprises in Austria: Strategic drivers for spatial orga- nisation
}

\begin{abstract}
Research and development (R\&D) activities of firms are becoming increasingly internationally organised, with a growing number of new locations in emerging economies and an increasing number of small and medium-sized enterprises tapping into internationalisation. The aim of this paper is to link international R\&D strategies of small and medium-sized enterprises to the spatial organisation of R\&D activities. A survey of Austrian firms forms the basis of the analysis. The findings show a clear spatial concentration of foreign R \& D activities of Austrian firms in Western and Eastern Europe, especially Germany. However, this general distance decay function is distorted by regions' evolutionary trajectories and their peculiarities, such as cultural and cognitive proximity, and by the scope of $\mathrm{R} \& \mathrm{D}$ envisaged by the firm. The analysis reveals that knowledge-exploiting strategies are more common for activities in emerging economies, whereas knowledge-gaining and learning strategies drive the establishment of activities in countries with an advanced national innovation system. Furthermore, small and medium-sized firms tend to internationalise via international cooperation rather than via the establishment of own subsidiaries abroad. Plans for future activities show only limited change in this respect.
\end{abstract}

Keywords: R\&D internationalisation, firm strategies, spatial otrganisation, Austria, small and medium-sized enterprises

JEL Classification: L22 - Firm Organization and Market Structure, O32 - Management of Technological Innovation and R\&D, R11 - Regional Economic Activity: Growth, Development, Environmental Issues, and Changes

\section{Introduction}

It is a widely known and discussed fact that firms internationalise their Research and Development $(R \& D)$ activities. Firms' R \& D networks are growing in space with the highest dynamic in emerging economies. This is due to the phenomenal improvements and significant cost reduction in communication infrastructure (BLINDER 2006; LEVY 2005; CONTRACTOR et al. 2010) and to governmental policy change, such as the liberalisation of foreign direct investment (FDI) regimes and tighter enforcement of intellectual property rights in many countries (UNCTAD, 2009). Furthermore, firms have started to use external knowledge sourcing more frequently instead of internal R\&D organisation as spatially and organisationally distant knowledge can be more inspiring (BIERLY et al. 2009).

Although these trends are being intensively discussed, the pattern of R\&D internationalisa- tion cannot yet be fully explained and existing studies reveal limitations. Firstly, R\&D internationalisation is driven by large multinational enterprises (MNE). Small and medium-sized enterprises (SME) are expected to follow, but are generally neglected in the literature on R \& D internationalisation. MAssini/Miozzo (2012) and HSUAN/MAHNKE (2011) call for a correction of the large firm bias. Empirical studies are needed to research whether SMEs adopt innovation offshoring strategies of large MNEs or develop their own strategies due to limited resources. Secondly, R\&D internationalisation of firms is often explained by the attractiveness of target regions using data gained from national statistics (e. g. wage level, share of highly qualified workers). Strategic motives of firms are rarely taken into account. If strategic drivers are directly identified, they mainly mirror firms' $R \& D$ internationalisation in general, but hardly relate to locational or organisational choices at the same 
time. This leads to the third shortcoming, the one-dimensional (strategy, target countries or organisational mode) view of R \& D internationalisation. Moreover, an outlook to future activities related to existing $\mathrm{R} \& \mathrm{D}$ internationalisation patterns is rarely reflected upon.

The aim of this paper is to deal with some current shortcomings on $\mathrm{R} \& \mathrm{D}$ internationalisation and to answer the following questions: How do firms' strategies determine the spatial and organisational pattern of R\&D activities (1) from a conceptual point of view and (2) from an empirical perspective taking into account the small and open economy of Austria? The paper attempts to explain the R\&D internationalisation pattern using a multidimensional perspective consisting of the interrelation of strategic motives, locational choice and organisational modes.

The analysis is based on a firm survey of SMEs in Austria carried out in 2010. The sample gathered includes 410 firms. The survey method gave us the chance to gain information on strategic drivers for $\mathrm{R} \& \mathrm{D}$ internationalisation for specific countries instead of relying on secondary data. The empirical findings show that half of the Austrian SMEs surveyed - the back bone of the Austrian economy - perform international R\&D activities. Firms prefer to work with partners in cooperative modes. Over $70 \%$ of international R\&D activities of the Austrian firms are performed in Western Europe, particularly in Germany, followed by Eastern Europe. Only a few activities are located in North America and Asia. R\&D activities abroad follow a clear distance decay function, as R \& D needs some sort of spatial and cultural proximity. This responds to the calls by MASKELL et al. (2007) and LEWIN et al. (2009) for a more dynamic view of R\&D offshoring.

The paper is divided into a conceptual, method, empirical and concluding part. In the conceptual part, the interlinkages of strategic drivers for R\&D internationalisation, organisational modes and locational choice are discussed. This is followed by the introduction of the main data source and the applied methods. The empirical part presents evidence from an Austrian firm sample on the interlinkages of the three dimensions. Moreover, it provides an outlook on future dynamics of R \& D internationalisation. The conclusion summarises the findings and delivers a more distinct picture of $\mathrm{R} \& \mathrm{D}$ offshoring.

\section{Firms' perspective on $\mathrm{R} \& \mathrm{D}$ internatio- nalisation: A conceptual view}

In the following it is argued that firms' $\mathrm{R} \& \mathrm{D}$ strategy determines the locational choice of R \& D activities and their entry modes. There are R\&D activities that are highly knowledge intensive and specialised and other that are more standardised. Depending on the strategic choice of firms what type of R\&D activity they want to strengthen, locational choice in terms of advanced or emerging economies as well as distant or proximate economies is taken. Depending on the locational capacities the entry mode is selected.

\section{Internationalisation of $R \& D$ activities in global value chains}

The global value chain concept (GVC) provides a pragmatic and useful frame to answer questions on the spatial dispersion of value creation activities and their organisation (STURGEON et al. 2008). MUdAMBi (2008) presented the "smile of value creation", while looking at the value added of different activities and at the same time the disaggregation of the value chain. He roughly distinguishes between basic and applied R\&D activities in the upper end of the value chain that relate to high value activities, the manufacturing and standardised services in the middle of the GVC that relate to lower value activities and finally the marketing, logistics and after sales activities that again relate to higher value added (see Fig. 1).

The spatial pattern corresponds to the value added of the activities. Accordingly, the start and end of the chain is expected to be largely located in advanced market economies, while the manufacturing activities are relocated and often outsourced to emerging economies. "Increasing modularization allows the firm to amplify its core focus on narrower activities within the value chain associated with the highest value added, an approach which may be called 'fine slicing'. In tandem, it allows the firms to outsource other activities (associated with lower value added) more cheaply and efficiently." (MudAMBI 2008, 708). Firms to which these lower value added activities are outsourced use this opportunity to upgrade and realise increasingly more value added activities (OECD 2008). Examples of this development can be found in the athletic shoe industry, in the auto industry or the electronics industry. 
Fig. 1: Upper end of global value chain

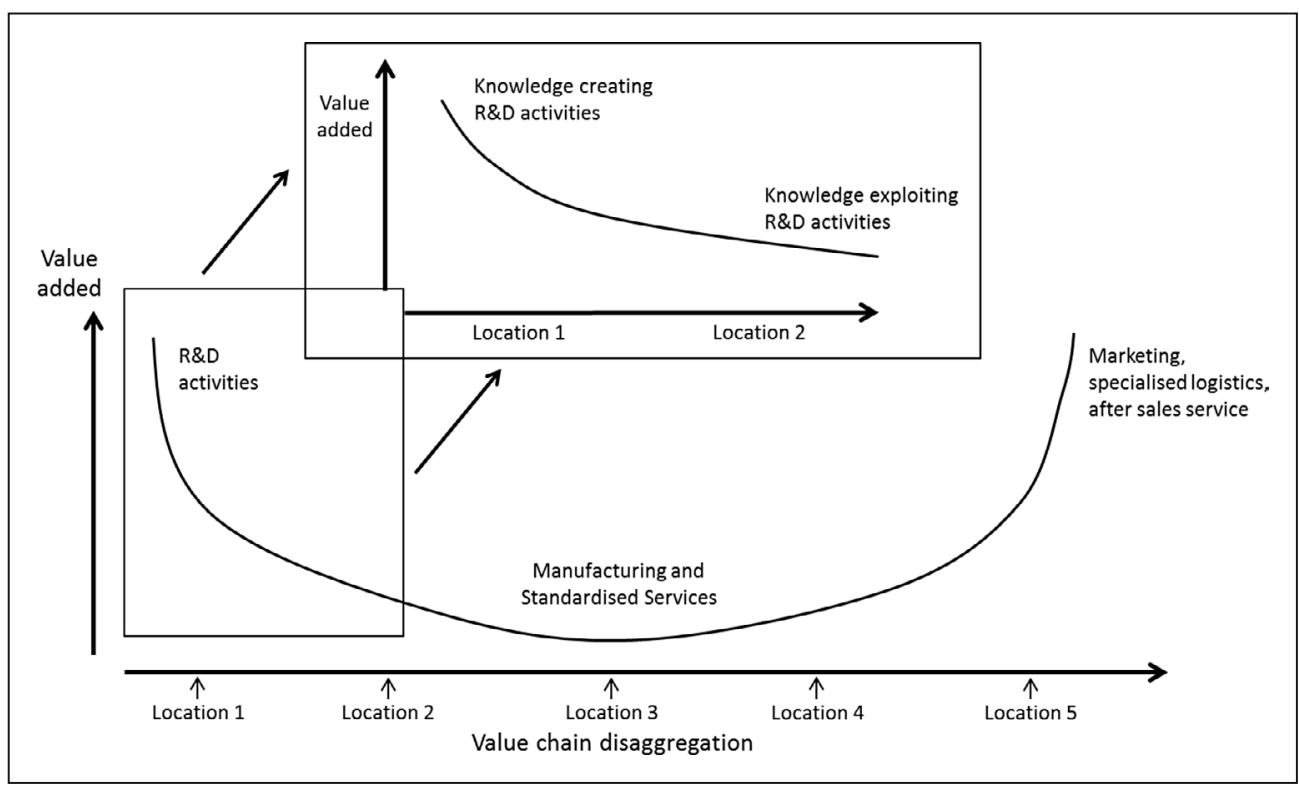

Source: Adapted from MudAMBI (2008)

In this research, we only focus on a specific fraction of the GVC - namely the upstream end of $\mathrm{R} \& \mathrm{D}$ activities. We assume that even within the highly value added activities, fine slicing takes place. Already, Kuemmerle (1999) differentiates the strategic choice of firms between homebased augmenting versus home-based exploiting activities. This differentiation can also be related to $\mathrm{R} \& \mathrm{D}$ activities distinguishing $\mathrm{R} \& \mathrm{D}$ aiming on the creation of new knowledge and technologies with very high value added and those aiming on exploitation of competencies. Other related typologies following this dichotomy are strategic asset seeking versus market or resource seeking activities (DUNNING 1995; 1996) or knowledge creating versus knowledge exploiting activities (CANTWELL/MUDAMBI 2005) which we follow.

Hence, R\&D strategies targeting on the creation of knowledge are largely supply driven. For knowledge creating activities spatial proximity to other firms with high knowledge value is crucial. Furthermore, supporting regional institutions are of highest importance to protect their intellectual property right (GERTLER 2003; MALMBERG/MASKELL 1997). Innovations are more likely to emerge when the knowledge of different players is combined. Firms can absorb this knowledge for in-house use. Hence, there is a need for external knowledge inputs like new technology, highly qualified science and engineering talents and networks. This makes knowledge creating activities costly (FLORIDA 1997; Serapio/Dalton 1999; Manning et al. 2008; Cantwell 1989; Kuemmerle 1999; LEWIN et al. 2009; PEARCE 2009; DunNING 1998; DunNING/NARULA 1995).

In contrast, $R \& D$ activities aiming on the exploitation of competencies are demand driven. Firms enter and secure markets abroad while exploiting firm-specific knowledge and capabilities in foreign environments, e.g. through cost reduction (Hymer 1960; KuemMerLe 1999; GamMELTOFT 2006). However, a global production and commercialisation requires a customisation of products for specific markets (with respect to climate, technical norms, standards, customer needs). These innovations call for R \& D activities conducted directly in the target country, as the innovation process requires feedback loops with customers. (HYMER 1976; DUNNING/NARULa 1995; Gammeltoft 2006, Massini/Miozzo 2012). In order to exploit knowledge, it must be appropriated and to some extent standardised (e.g. development activities for market adaptation and production support) to a level which al- 
lows it to travel over distance (MUDAMBI 2008). The different R\&D strategies of firms call for specific locational choices.

However, managers of firms, especially in SMEs, suffer under bounded rationality (SIMON 1991). Managers are limited by the information they have, the cognitive limitations of their minds, and the finite amount of time they have to make a decision. Most SMEs are family-led, which makes it difficult for foreigners to step in and add experience to the SMEs. Managers of SMEs base their decision on $\mathrm{R} \& \mathrm{D}$ organisation abroad on their personal often limited international experience (no perfect information). However, each decision has consequences which enable managers and therefore SMEs to learn. Especially in family-led SMEs this knowledge and experience is stored for an entire generation within the organisation and can be used any time. If SMEs take choices on strategies (knowledge exploitation or knowledge creation) and locations, we can assume bounded rationality.

\section{Location choice}

According to MudamBi $(2008,702)$ "firms increasingly implement strategies to take advance of the comparative advantages of locations." Comparative advantages of different locations are evaluated against the costs of spatially dispersed operations. Different strategic motives drive firms to different specific locations. Although this phenomenon is well known (e.g. VON ZeDTWITZ/GASSMANN 2002; EdLER et al. 2002; THURSBY/ThursBy 2006), we often only find a distinction between motives driving firms to advances in comparison to emerging economies. This view needs a spatial distance perspective in order to differentiate additionally between distant and proximate economies, as knowledge is "sticky" and distance-sensitive. This is especially true for implicit knowledge, which is most important for innovation. Boschma (2005) already started to work systematically on different interpretations of proximity.

R\&D activities with knowledge creation mandate and high value added activities are largely performed in economies with an advanced innovation system, e.g. Western Europe, North America or Oceania (MUdAMBi 2008). JENSEN/ Pedersen (2011) revealed that Danish firms' R \& D activities are significantly more often conducted in North America if they follow a competence creating strategy. These locations provide the appropriate quality and access to knowledge and technology. Moreover, the system is open and transparent; institutions are in place to secure the generation of knowledge. In case of European origin of the firm, institutional proximity is given. However, internationalisation of $R \& D$ as such is no motive. $R \& D$ becomes international if the partner is located abroad. Especially for small economies like Austria knowledge sourcing from partners abroad is common as only a reduced number of domestic partner with specific competencies are available. This picture might look different for firms in the US, who can find partners for knowledge creation domestically.

Knowledge exploiting activities are often performed in countries with an emerging innovation system. Jensen/Pedersen (2011) showed for Danish firms that they conduct less advanced and standardised activities of R\&D in Eastern Europe and Asia. As regions would like to be attractive for international $R \& D$ centres, they sometimes offer policy incentives (e.g. capital subsidies, loans, tax allowances, R\&D support). However, CANTWELL/MudAMBI (2000) collected evidence that even lucrative policy incentives do not attract competence creating R \& D activities of firms, but work well to attract competence exploiting $R \& D$ activities.

Jensen/Pedersen (2011) showed that Danish firms have expanded their offshoring beyond the proximate "home" market in Western Europe to emerging economies all over the world, but preferentially to Eastern Europe. "This again highlights the importance of proximate location - for firms based in Denmark, Eastern Europe offers a mixture of proximity and low cost" (JENSEN/ Pedersen 2011, 365). Ambos/Ambos (2011) also show negative effects when firms establish a knowledge sourcing hub in culturally distant economies, taking German MNEs as an example. Proximity apparently still matters in R\&D internationalisation. Although Eastern European countries are emerging - as Asian countries are as well - uncertainty is perceived lower in those countries as they are in proximity rather than in distance. Face-to-face contacts can still be realised and this enables knowledge spillovers (STORPER 1995). However, distance is not limited to space, but also includes "psychic distance, defined in terms of factors preventing or disturbing the flow of information between the firm and the target nation, including linguistic, institutional, cultural and political factors" (AM- 
Bos/Ambos 2011, 110). Adjustments to the new environment need to be learned, which remains an obstacle for firms and causes significant costs, especially in regions like Asia (ZAHEER/MANRAKHAN 2001; CONTRACTOR et al. 2010). In conclusion, beside the advancement of the innovation system, proximity in terms of space, culture and cognitive behaviour matters for business R \& D internationalisation.

\section{Entry mode}

Knowledge intensive activities are usually highly localised, but external "pipelines" (BATHELT et al. 2004) can also transfer appropriated knowledge. If we take the value chain picture again, knowledge created in the very upper end is difficult to transfer, but knowledge related to exploiting activities is easier to move once it is appropriated (GERTLER 2003). Transfer channels often have an organisational dimension, e.g. in the establishment of subsidiaries or through trust based inter-firm cooperation. Knowledge travels through the routine or relocation of engineers and managers (SAXENIAN 2006), sometimes by new communication technologies. Accordingly, firms adapt their entry mode to the R\&D strategy on the one hand and to the specific characteristics of the target location on the other hand.

Mudambi/TALLman (2010) gave reasons why the organisation of $R \& D$ is not limited to a make or buy decision, as was conceptually and empirically discussed for production processes. They argue that firms seek organisational structures "that both protect and leverage their strategic knowledge assets, with the final decision often coming down to a choice between different alliance forms" (MUDAMBI/TALLMAN 2010, 1434). Cooperative modes, according to WiLLIAMSON (1991) being a subtle distinction between internal and external solutions. Cooperative modes better fit to the special characteristics of knowledge inherent to $R \& D$ activities (high value, highly tacit, involving investments in human capital, highly transaction-specific investments, high risk, strategic decisions). Especially knowledge creating $\mathrm{R} \& \mathrm{D}$ activities might be efficiently organised in cooperative modes as access to new knowledge and scientific infrastructure can be ensured. However, cooperation also offers incentives for the organisation of competence exploiting activities, namely labour cost savings and the ability to respond quickly to changing markets (MUDAMBI/TALLMAN 2010,1434$)$. Besides the type of R\&D the location specific characteristics influence the entry modes. Meyer (2011) e.g. shows that firms adapt their organisational mode in response to differences in the regional formal (legal, political and administrative systems) and informal institutions (relationships and social norms).

\section{Path dependency and organisational evolution}

Besides the strategic motives and the related locational and organisational feature steering R \& D offshoring, other external factors can be important driving forces. The resourced based view of firms (PENROSE 1959; WERNERFELT 1984) points to the tangible or intangible resources at the firm's disposal to grow competitive. Especially SMEs have limited financial and managerial resources available, have limited access to additional financial resources and only profit partially from economies of scale (Economist Intelligence Unit 2011). However, SMEs profit from speed and flexibility, lack of bureaucracy, effective communication and decision-making, close customer ties and the opportunity to niche the market. This enables them to be competent and flexible partners. For Swedish SMEs RoVIRA NORDMAN/TOLSTOY (2011) proved that product flexibility may strengthen personal interaction with foreign customers, which in turn enhances technology innovation.

Another issue that must be raised is path dependency and organisational learning. Firms already having an established R\&D network are likely to rely on it instead discovering new locations. GLUECKLER (2007) shows that economic actors are likely to deepen ties with partners they already have interactions with. Furthermore, MARTIN/SUNLEY (2006) showed that firms tend to gravitate to the local environment even though access to distant resources might be beneficial to them. These arguments can be confirmed when looking on the R\&D investments. Concentrating on the $R \& D$ investment dynamics, traditional locations seem to be on their way to losing their attractiveness for R \& D investment (HugGins et al. 2007), but looking at the R\&D investment stocks, economies with an advanced national innovation system such as Western Europe and the NAFTA region are still leading (Demirbag/Glaister 2010).

However, also organisational learning and development takes place over time. Managers of SMEs gain experience and reduce uncertainty when taking decisions (SIMON 1991). When set- 
ting up international $\mathrm{R} \& \mathrm{D}$ relations SMEs learn step by step what organisational mode works best in which location. They learn better how to select partners and establish a trustful relationship. In contrast to MNEs they have limited financial resources and limited time for experiments.

Frequently referred to as co-evolutionary dynamics, the factors which shape the strategic decisions concerning $\mathrm{R} \& \mathrm{D}$ offshoring are macroeconomic forces, host and home country's offshore policies, industry dynamics and firm-level offshoring capabilities (MANNING et al. 2008). However, the decision in favour of R\&D offshoring is not always a conscious process, but sometimes a "side product" of locational choice for production and distribution sites (BELITZ 2004) or a result of mergers and acquisitions. R\&D offshoring depends greatly on the path and resources of firms. LEWIN et al. (2009) summarised reasons emerging in the literature that determine offshore decisions with respect to R\&D:

- Tangible and intangible resources build the basis for R\&D internationalisation.

- Behavioural and evolutionary assumptions of firms suggest that rules and routines used by firms lead to the continuation of existing R \& D sourcing (mainly internally and close to headquarters), even if environmental dynamics paint a different picture.

- Firms' past experiences influence managers' perceived choices of opportunities for R\&D internationalisation decisions.

- Transaction costs suggest that firms hesitate to change their organisational modes (from internal to external R\&D sourcing) or their location in space. It is risky and costly to experiment with new forms and locations of R\&D.

\section{Combining the strategic, organisational and locational perspective - the SME's point of view}

The strategy of SMEs and their locational pattern to internationalise $\mathrm{R} \& \mathrm{D}$ activities is expected to be different from MNEs. They have limited resources to set up own R\&D centres in locations to overcome high uncertainty. To access and benefit from knowledge and technology gen- erated abroad, a more open and flexible mode, such as hybrids (cooperation), seems to be more advantageous for firms. SMEs opt for countries in proximity, where they can better control activities organised in cooperative forms.

So far, the literature has mainly focused on motives driving firms to emerging or advanced economies (e.g. Thursby/Thursby 2006), but distance is also important. Advanced economies are not always close and emerging economies are not always distant. In advanced and proximate economies, the main driver is knowledge creation due to the advanced innovation system and due to cognitive and cultural proximity. At the same time, especially SMEs benefit from efficient control and coordination actions in R \& D activities. They enjoy a stable policy framework. In advanced and proximate economies the probability of SMEs to work in cooperative or external relations is high, as uncertainty is low. Firms have control over market action, cognitive proximity is supportive and coordination is eased. However, advanced and proximate economies are mainly locations for the first step of R \& D internationalisation. This is when path dependency starts, for example routines lead to a continuation of existing R \& D sourcing, transaction costs for changing locations are perceived as high, but regional embeddedness of existing activities leads to continuation. Although cooperation or external modes might be most appropriate for the situation, path depend might be the reason for inhouse $R \& D$.

In emerging and proximate economies, production and cost-efficient motives combined with attractive $\mathrm{R} \& \mathrm{D}$ policies are the main drivers. Path dependency is of reduced importance. For emerging economies in proximity, the picture how SMEs organise their R \& D activities is less clear. Proximity allows for social control and trust-based governance which fits with the features SMEs incorporate, but the emerging status requires a certain degree of control. Most likely, cooperative relations can combine the elements needed.

Advanced regions at distance are close in cognitive terms, provide mature policy conditions and favour knowledge-augmenting opportunities. An open-access mode encourages knowledgeseeking activities, but $\mathrm{R} \& \mathrm{D}$ activities at distance require specific control and coordination mechanisms. Again, cooperation might serve this situation best. Due to the specific traits of 
knowledge-intensive activities discussed before, the share of cooperative $R \& D$ is expected to be high.

Emerging and distant economies are at cultural and cognitive distance with no path dependency for most of the European firms, but knowledgeexploiting motives (markets, production) and attractive $\mathrm{R} \& \mathrm{D}$ policies are the gravitation points. However, location-specific environmental uncertainty (e.g. volatile and unpredictable market conditions, policy instability) and behavioural uncertainty (e.g. inexperience in business culture and longer reaction time in distant economies) might have the greatest influence in steering the decisions of firms on hierarchies, which makes it again difficult for SMEs to enter those countries as it would be very costly for them.

From this discussion the following hypothesis were derived:

Hypothesis 1: SMEs perform parts of their R \& D activities internationally.

Hypothesis 2: International R\&D of SMEs is mostly performed in cooperative or external organisations.

Hypothesis 3: R\& D activities aiming for knowledge creation are more likely to be organised in economies with an advanced innovation system, whereas R\&D activities related to competence exploiting are more likely to be organised in countries with an emerging national innovation system.

Hypothesis 4: Distance matters for firms, they prefer proximate economies rather than distant target regions for $\mathrm{R} \& \mathrm{D}$ offshoring.

Hypothesis 5: Internal organisation of $\mathrm{R} \& \mathrm{D}$ offshoring is preferred in emerging and distant economies. Cooperative and external organisation of R \& D offshoring is preferred in advanced and proximate economies.

\section{Data sampling and methods}

\section{Data and methods}

Austria is a small and open economy in the centre of Europe. The backbone of the Austrian economy is formed by SMEs. SMEs are therefore of high relevance for the competitiveness of the national innovation systems. Therefore,
Austria has been selected as a study case for this analysis. Due to its limited size of Austria firms more often search for excellent R \& D partners abroad, which gives us the opportunity to study their strategic behaviour, locational choices and organisational modes. Austria has close economic ties with Germany and Switzerland, which enables cross-border R\&D organisation. Austria serves as an example for a small economy in Western Europe which opened up economically very early. SMEs in Austria are expected to be quite advanced and experienced in the internationalisation of $\mathrm{R} \& \mathrm{D}$. The analysis is based on survey data of Austrian firms which were collected in spring and summer 2010 using an electronic questionnaire. The sample consists of all firms that applied for R\&D and innovation funding at the Austrian Research Promotion Agency (Österreichische Forschungsförderungsgesellschaft FFG) from 2005 onwards. All firms within the sample conduct research (incl. basic and applied research) or development activities. The FFG provided a list with names and electronic contact details for about 6,300 firms. After cleaning and supplementing the database, questionnaires were electronically sent to 5,700 firms. About $14 \%$ of the e-mail addresses were inactive, hence the actual sample frame was reduced to 5,100 firms. Firms were reminded using first a written and then a telephone reminder (730 firms with more than ten employees and R \& D staff of more than three persons according to the FFG database). As a result, 410 completed questionnaires were received (resulting in an actual response rate of $8 \%$ ).

The questionnaire consists of six thematic blocks:

- characteristics of the enterprise (a. o. sector, ownership, turnover, employees, access to capital, exports, FDI) and its market environment (number of competitors, information on the type of competition),

- basic information on R\&D activities (R\&D personnel, R\&D expenditure, type of domestic and foreign $R \& D$ ),

- specific questions concerning R\&D activities abroad (type of $R \& D$ according to location, motives),

- consequences of the foreign R \& D activities,

- obstacles to (more) R\&D activities abroad,

- future plans with respect to foreign R\&D (according to type and location). 


\section{Sample characteristics}

About one third of the enterprises in the sample are small firms with less than ten employees in Austria, 28\% have between ten and 49 employees, $20 \%$ between 50 and 249 employees and $19 \%$ employ a workforce of 250 or more (employee numbers for 2009). The sample mirrors the traditionally high share of SMEs $(<250$ employees). Although $19 \%$ of firms have more than 250 employees, they are not MNEs, but reflect larger Austrian firms in traditionally strong sectors of the Austrian economy. It is expected that their behaviour is more closely related to the SMEs than to MNEs. Therefore, we do not expect a bias from keeping those firms in the sample. We understand Austrian firms in this sample as SME-like firms.

$64 \%$ of the firms in the sample are individual enterprises, while the remaining $36 \%$ belong to an enterprise group. About one third of these are part of a foreign group, i. e. mainly subsidiaries of German enterprises (43\%). In terms of sector affiliation, slightly more than half of the sample belongs to manufacturing ( $51 \%$ ), while $44 \%$ of the enterprises offer services (The remaining $5 \%$ stem from sectors such as energy/ water supply, construction). A fairly high share of $25 \%$ of firms have their main activity in professional, scientific and technical activities (M) and administrative and support service activities (N). $13 \%$ of the firms offer ICT services. The dominating branches within manufacturing are machinery and equipment $(\mathrm{C} 28 ; 10 \%)$ and the manufacture of computer, electronic and optical products $(\mathrm{C} 26 ; 8 \%) .{ }^{1}$

Compared to the latest structural business statistics (2008), our sample is biased towards manufacturing and against certain services (e. g. construction, retail trade, financial activities). This is a typical situation for R\&D activities. Hence, a comparison with the latest R\&D survey (2007) shows a certain bias in favour of professional services and against retail/wholesale trade ${ }^{2}$.

\section{R \& D internationalisation of Austrian firms}

The empirical section is organised as follows. Firstly, the survey findings show statistics on the R\&D locations/partners, organisational modes and strategic motives. Secondly, the three findings are tied together in a network graphic to make $R \& D$ internationalisation patterns of SMEs visible. Finally, a future outlook is provided on the development of $\mathrm{R} \& \mathrm{D}$ locations/ partners abroad.

Survey findings of Austrian firms on strategic motives, locational choice and $R \& D$ organisation

The survey sample for this study is tailored to $\mathrm{R} \& \mathrm{D}$ performers. According to the Coтmunity Innovation Survey (Figure for 2006-2008; Statistik Austria 2010), 20\% of all firms in Austria with more than nine employees conduct in-house R \& D either continuously (12\%) or discontinuously $(8 \%)$. This specific survey was designed to learn more about the behaviour of R \& D performing SMEs. The survey asked firms to indicate their five most important R \& D relationships abroad. For each relationship, firms provided information on location, organisational mode and strategic drivers. R \& D partners are other firms, universities or research organisations. This enabled us to focus our analysis on the level of $\mathrm{R} \& \mathrm{D}$ relations rather than on the firm level. We assume firms to use different R \& D relationships for different strategic goals.

We distinguish between three types of R\&D performers: a) closed and concentrated $R \& D$ performers that only conduct internal $R \& D$ domestically, b) open and concentrated R\&D performers that perform $\mathrm{R} \& \mathrm{D}$ domestically but in an open manner (including $\mathrm{R} \& \mathrm{D}$ cooperation and outsourcing) and c) international R \& D performers that conduct R \& D abroad either internally, externally or in a cooperative way. The three categories mirror an increasing openness and internationalisation from a) to c).

Fig. 2 indicates the share of $\mathrm{R} \& \mathrm{D}$ performer types according to firm size (in Austria). Only $13 \%(n=48)$ of all R\&D firms are organised in a closed and concentrated way. $35 \%(n=130)$ are restricted to domestic networks, and $51 \%$ (n $=184$ ) are active on an international level. A comparison according to firm size reveals that SMEs (<250 employees in Austria) are less internationally active than larger firms, but nevertheless, $46 \%$ of firms with less than nine employees perform R\&D activities abroad. The international type is most common regardless of size class. This proves that SMEs have started to follow MNEs in the internationalisation of $\mathrm{R} \& \mathrm{D}$ activities. It is therefore worth studying 
Fig. 2: Share of R\&D performer types according to firm size (number of employees)

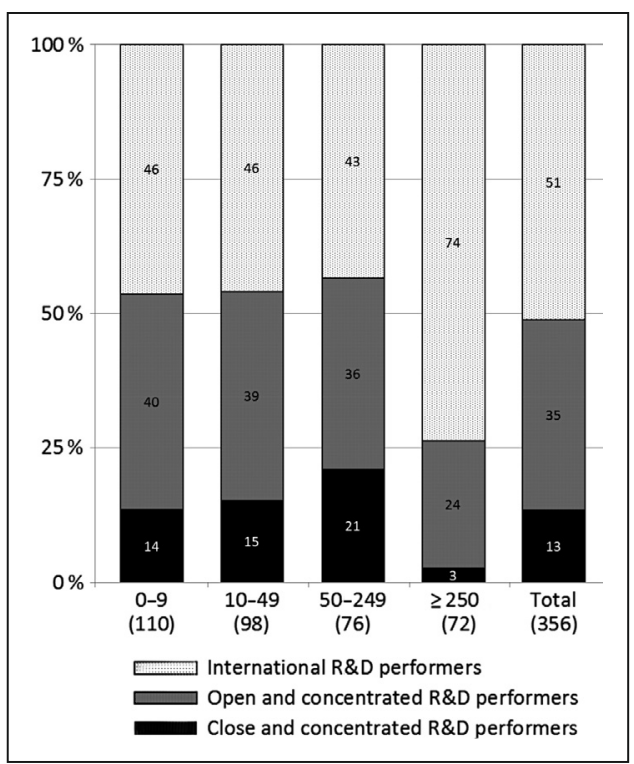

Source: Authors' survey and calculations

where Austrian firms perform their R \& D activities and how they organise them.

In Tab. 1 all relevant $\mathrm{R} \& \mathrm{D}$ relations of Austrian firms are analysed, although one firm can have more than one $R \& D$ relationship. The table provides a detailed look at the $\mathrm{R} \& \mathrm{D}$ activities performed domestically and internationally. We further distinguish between internal R\&D (includes all R\&D activities that are conducted within the entire enterprise group), external $\mathrm{R} \& \mathrm{D}$ (research that is contracted to external research organisations or enterprises) and cooperative R\&D (short or long-term team building of two or more independent (not capital or legal dependency) enterprises to follow a specific R \& D activity). In total, $87 \%$ of all R \& D performers conduct internal R\&D in Austria, $64 \%$ have R\&D collaboration and $52 \%$ outsource R\&D. In contrast, only $16 \%$ of all studied Austrian SMEs have own R \& D subsidiaries abroad, while $38 \%$ of firms collaborate with foreign partners in R\&D, and $27 \%$ source R\&D services from foreign contractors. We can already see how the organisational pattern shifts from internal in domestic R \& D to cooperative modes for international R \& D activities. Arguments by Mudambi/TALlman (2010) emphasise a push towards more cooperative R \& D for SMEs. Austrian firms seek cooperative modes to protect and at the same time leverage their knowledge. Moreover, cooperative R \& D saves costs for setting up and operating R\&D facilities for SMEs, which usually have limited budgets. Another advantage is the flexible and quick reaction to market changes.

In general, large firms with 250 employees or more have a higher share of R\&D-active firms over all organisational modes compared to SMEs. A clear size threshold can also be observed for internal R \& D. Internal R \& D abroad obviously increases constantly with size, while the share of firms with external or cooperative $\mathrm{R} \& \mathrm{D}$ abroad is similar within the SME categories.

The studied 410 SMEs in Austria indicated to have at least 679 international $\mathrm{R} \& \mathrm{D}$ relations. In the survey, firms were asked about the locations (country) of their five most important foreign $R \& D$ sites, partners and contractors. These

Tab. 1: Organisational mode of $R \& D$ activities according to location and firm size

\begin{tabular}{|c|c|c|c|c|c|c|}
\hline \multirow[t]{2}{*}{ Size } & \multicolumn{3}{|c|}{ In Austria $^{1}$} & \multicolumn{3}{|c|}{ International $^{2}$} \\
\hline & $\begin{array}{l}\text { Internal R\&D } \\
\quad(\mathrm{n}=344)\end{array}$ & $\begin{array}{l}\text { External R\&D } \\
\quad(n=204)\end{array}$ & $\begin{array}{l}\text { R\&D cooperation } \\
\quad(\mathrm{n}=251)\end{array}$ & $\begin{array}{l}\text { Internal R\&D } \\
\quad(n=62)\end{array}$ & $\begin{array}{l}\text { External R\&D } \\
\quad(n=108)\end{array}$ & $\begin{array}{l}\text { R\&D cooperation } \\
(\mathrm{n}=151)\end{array}$ \\
\hline $0-9(n=132)$ & $77 \%$ & $45 \%$ & $58 \%$ & $3 \%$ & $22 \%$ & $35 \%$ \\
\hline $10-49(n=110)$ & $88 \%$ & $47 \%$ & $64 \%$ & $9 \%$ & $24 \%$ & $35 \%$ \\
\hline $50-249(n=79)$ & $95 \%$ & $51 \%$ & $57 \%$ & $20 \%$ & $20 \%$ & $32 \%$ \\
\hline$\geq 250(\mathrm{n}=78)$ & $92 \%$ & $73 \%$ & $78 \%$ & $41 \%$ & $48 \%$ & $54 \%$ \\
\hline Total $(n=399)$ & $87 \%$ & $52 \%$ & $64 \%$ & $16 \%$ & $27 \%$ & $38 \%$ \\
\hline
\end{tabular}

1 Chi-square test: statistically independent $(0.5142<9.4873)$

2 Chi-square test: statistically dependent at 0.05 significance level $(20.1983>9.4873)$

Source: Authors' survey and calculations 
were aggregated to country groups. Tab. 2 depicts the high concentration in Western Europe (EU-15/EFTA) which accounts for $71 \%$ of all R\&D locations (with Germany alone taking the lion's share of $41 \%$ ), followed by Eastern Europe with $14 \%$ (New Member States NMS and Central and Eastern Europe CEE), the North America region (NAFTA) with 7\% (mainly in the US) and Asia with 5\%. Hence, we are witnessing a clear distance decay function, which is reasonable since $\mathrm{R} \& \mathrm{D}$ requires some sort of spatial and cultural proximity. JENSEN/PEDERSEN (2010) worked on a qualitative assessment of locations attributes explaining firms' offshoring activities in general. They also distinguish the four major regions: Western Europe (EU-15), Central and Eastern Europe (CEE), North America, and emerging countries in Asia. However, North America and Western Europe are related to good quality of human capital. Asia is leading in the availability of human capital with low wage levels. Moreover, the interaction distance in spatial terms is considered by them to be low in Western and Eastern Europe but high in North America and Asia. Language and cultural-wise is the distance in Western Europe and North America low and medium, whereas it is high in Central and Eastern Europe and Asia. Some of the attributes are more important for R\&D than others. However, the high quality of human capital and the low spatial and cultural interaction distance could well explain the dominance of Europe as a destination of R\&D of Austrian SMEs. We can also depict from the table that firms with more than 250 employees more often source from the North America region than SMEs.

The table also shows the average number of foreign $R \& D$ partners/locations per firm according to firm size. While micro firms have on average only one R\& D location or partner abroad, firms with 50-249 employees have 1.5 locations/partners on average, and for larger firms this number rises to 3.5. As expected, the number increases with firm size, since larger firms have more resources to organise foreign $\mathrm{R} \& \mathrm{D}$ activities.

Taking the organisational modes into account, there also seems to be a distance decay pattern. Internal R\&D is more spatially dispersed, even though it is still strongly focused on Europe (Tab. 3). The higher share of internal R\&D locations in Asia and North America indicates the need to set up one's own facilities which are far away from headquarters. Cooperative and external R\&D is most often used in the EU-15 region, which could follow the argumentation that $\mathrm{R} \& \mathrm{D}$ activities in spatial and cultural proximity need less control.

We expect different organisational modes to also be associated with different strategic drivers (that can finally be associated with locational patterns). Fig. 3 presents strategic motives and their dominance in different organisational modes. We distinguish motives driving knowledge creating $\mathrm{R} \& \mathrm{D}$ activities and motives driv-

Tab. 2: Spatial distribution of international R \& D according to firm size

\begin{tabular}{|c|c|c|c|c|c|}
\hline & \multicolumn{4}{|c|}{ Number of employees } & \multirow[b]{2}{*}{ Total } \\
\hline & $0-9$ & $10-49$ & $50-249$ & $\geq 250$ & \\
\hline $\begin{array}{l}\text { Average number of } R \& D \text { locations/ } \\
R \& D \text { partners per firm }\end{array}$ & 1.0 & 1.3 & 1.5 & 3.5 & 1.7 \\
\hline Western Europe (EU-15/EFTA) & $68 \%$ & $74 \%$ & $70 \%$ & $71 \%$ & $71 \%$ \\
\hline Eastern Europe (NMS/CEE) & $21 \%$ & $15 \%$ & $10 \%$ & $12 \%$ & $14 \%$ \\
\hline Asia & $3 \%$ & $5 \%$ & $9 \%$ & $5 \%$ & $5 \%$ \\
\hline North America (NAFTA) & $5 \%$ & $6 \%$ & $4 \%$ & $11 \%$ & $7 \%$ \\
\hline South/Central America & $1 \%$ & $0 \%$ & $3 \%$ & $1 \%$ & $1 \%$ \\
\hline Africa & $1 \%$ & $0 \%$ & $0 \%$ & $0 \%$ & $0 \%$ \\
\hline Oceania & $0 \%$ & $0 \%$ & $3 \%$ & $1 \%$ & $1 \%$ \\
\hline Turkey/Middle East & $1 \%$ & $0 \%$ & $1 \%$ & $0 \%$ & $1 \%$ \\
\hline Responses* & 136 & 148 & 115 & 273 & 672 \\
\hline Cases & 132 & 110 & 79 & 78 & 399 \\
\hline
\end{tabular}

* Number of foreign R \& D locations and R \& D partners

Source: Authors' survey and calculations 
Tab. 3: Spatial distribution of international R\&D activities

\begin{tabular}{lccrrrrrr} 
& \multicolumn{2}{c}{ Internal R\&D } & \multicolumn{2}{c}{ External R\&D } & \multicolumn{2}{c}{ Cooperative R\&D } & \multicolumn{2}{c}{ Total } \\
& \multicolumn{1}{c}{$\mathrm{n}$} & \multicolumn{1}{c}{$\%$} & $\mathrm{n}$ & \multicolumn{1}{c}{$\%$} & $\mathrm{n}$ & \multicolumn{1}{c}{$\%$} & $\mathrm{n}$ & \multicolumn{1}{c}{$\%$} \\
\hline Western Europe & 49 & $49 \%$ & 125 & $73 \%$ & 307 & $76 \%$ & 481 & $71 \%$ \\
Eastern Europe & 21 & $21 \%$ & 21 & $12 \%$ & 52 & $13 \%$ & 94 & $14 \%$ \\
Asia & 15 & $15 \%$ & 8 & $5 \%$ & 12 & $3 \%$ & 35 & $5 \%$ \\
North America & 12 & $12 \%$ & 12 & $7 \%$ & 26 & $6 \%$ & 50 & $7 \%$ \\
South/Central America & 3 & $3 \%$ & 1 & $1 \%$ & 2 & $1 \%$ & 6 & $1 \%$ \\
Africa & 0 & & 0 & & 1 & $0 \%$ & 1 & $0 \%$ \\
Oceania & 1 & $1 \%$ & 4 & $2 \%$ & 2 & $1 \%$ & 7 & $1 \%$ \\
Turkey/Middle East & 0 & & 1 & $1 \%$ & 4 & $1 \%$ & 5 & $1 \%$ \\
\hline Total Responses & 101 & $100 \%$ & 172 & $100 \%$ & 406 & $100 \%$ & 679 & $100 \%$ \\
\hline
\end{tabular}

Source: Authors' survey and calculations

ing knowledge exploiting $R \& D$ activities. What can be depicted from the figure is that internal organisation in own $\mathrm{R} \& \mathrm{D}$ laboratories is more likely to be related to knowledge exploiting activities. Two thirds of the respondents of internal $\mathrm{R} \& \mathrm{D}$ organisation named supporting the production abroad and the relevance of the host market as the most important reasons. Production requires a customisation of products for specific markets. These innovations call for R \& D activities conducted directly in the target country. The customisation of products is the entry ticket to foreign markets. This might also explain why internal R\&D is most widely distributed and occurs in Western and Eastern Europe as well as in North America, Australia, and Asia. These are major markets that already might host production sites which - due to distance - can only partly be supported by R\&D facilities (and staff) at the headquarters location. This is at least partly a reflection of the fact that $\mathrm{R} \& \mathrm{D}$ centres are often the climax of a stepwise upgrading process of local production sites which gain functions and responsibilities over time.

Fig. 3: Share of firms assessing the following motives as important/very important for international $\mathrm{R} \& \mathrm{D}$

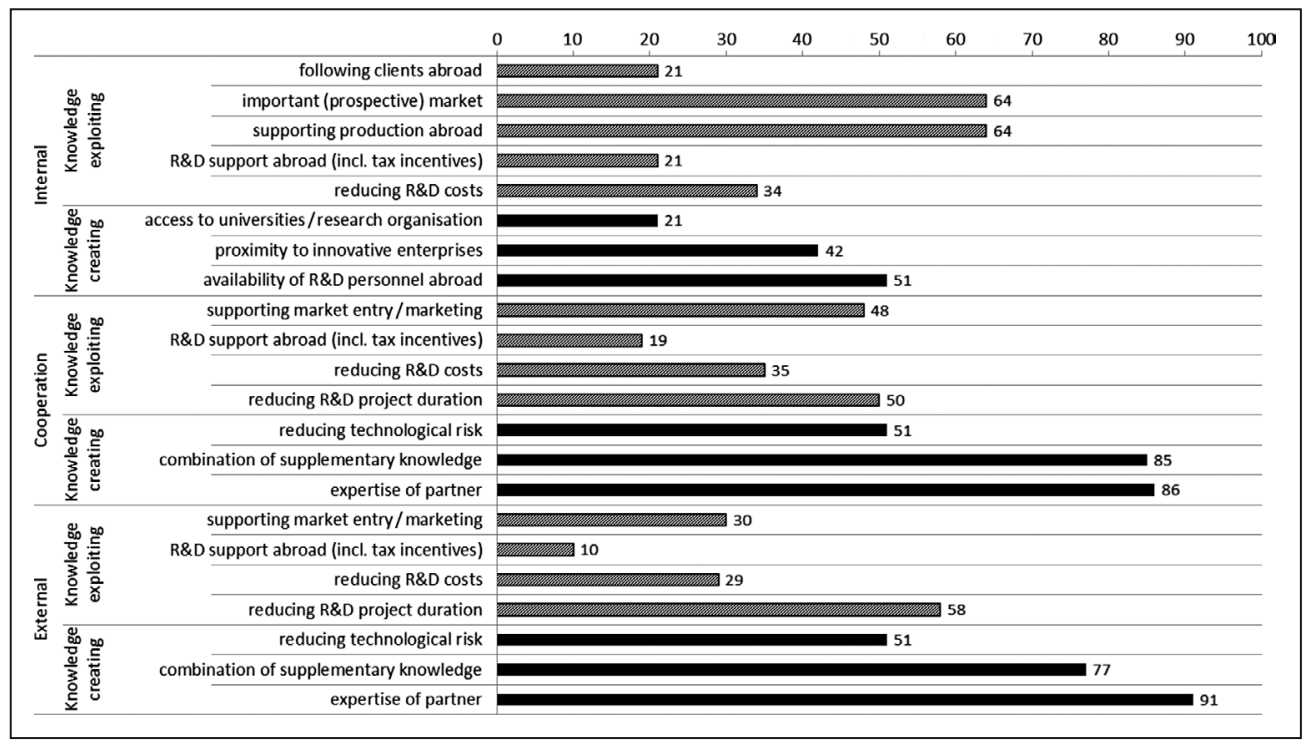

Source: Authors' survey and calculations 
$\mathrm{R} \& \mathrm{D}$ leading to knowledge creation is most likely to be realised in international R\&D cooperation or external relations: expertise of the partner and the combination of supplementary knowledge are by far the most important reasons for these types of foreign R \& D activities. In contrast, the reduction of cost does not play a crucial role. The open and flexible modes of cooperation and contracts in particular support the generation and back flow of knowledge to the firms.

The survey reveals insights into the organisation of international R \& D of SMEs. Out of 399 valid cases $80 \%$ (321 firms) belong to the group of SMEs $(<250$ employees in Austria). The analysis shows clearly that $40 \%$ of all SMEs are international R\&D performers. SMEs with less than 49 employees use mainly cooperative (approx. $35 \%$ ) or external (approx. $25 \%$ ) relations to organise their R\&D activities abroad. Only SMEs with 50 employees or more seriously start to build internal R\&D abroad. The survey also shows that SMEs tend to have one or two partners abroad (external or cooperative). Only if firms grow larger, the R\&D network of firms grows tremendously. SMEs in Austria prefer locations in spatial proximity looking for partners in Western and Eastern Europe. The analysis revealed that knowledge creating activities are the most important motives for external and cooperative R \& D. As SMEs count for $80 \%$ of the sample, we can assume that SMEs mainly use international R\&D networks to advance their knowledge. This can be best organised with partners in Western Europe as source for knowledge. Due to reduced financial resources the set-up of internal R\&D abroad is reserved for larger firms.

\section{Internal $R \& D$ on international level}

We have shown that strategic motives drive the locational choices as well as the organisational modes for R\&D activities of firms. In a final step we want to tie together the three dimensions to make the interrelation between those three more explicit. This exercise is conducted separately for internal and external/cooperative $\mathrm{R} \& \mathrm{D}$ at the international level.

For internal R\&D abroad, our sample encompasses 53 firms that have R \& D facilities abroad and that shared the information on the location of these facilities. In total, these 53 firms operate $101 \mathrm{R} \& \mathrm{D}$ facilities abroad (ranging from 1 to 5 sites per enterprise; the questionnaire asked about the max. five most important R \& D sites). As mentioned above, two thirds of all internal R \& D locations are concentrated in Europe.

For about $90 \mathrm{R} \& \mathrm{D}$ sites, the respondents answered questions about individual motives ( $\mathrm{min}$. 87; max. 91). The network diagramme in Fig. 4 shows the distribution of motives according to (aggregated) location, which allows for a distinct characterisation of each location. These selected locations are the most popular destination and have the following stereotype-like characteristics according to the development of the innovation system and locational distance: (1) Western Europe: advanced and proximate, (2) Eastern Europe: emerging and proximate, (3) Asia: emerging and distant, (4) Industrialised Countries outside Europe (NAFTA/Oceania): advanced and distant. The continuous line indicates proximate economies and the dashed line distant economies. Furthermore, the black line characterises advanced national innovation systems, and the grey line emerging national innovation systems.

An analysis of strategic drivers for R\&D sites in advanced/emerging and proximate/distant innovation systems revealed the following pattern: In general, the most important drivers of internal R\&D abroad over all regions are the ability to adapt products to local markets and enhance market perspectives. Only the establishment of own R \& D centres in Western Europe is used for knowledge creating activities. Although the North America region also offers knowledge creating opportunities, this is not what is important to SMEs if they set up own R\&D centres over there. However, there are some SMEs that also use own R \& D centres in Eastern Europe as base for knowledge creation due to the quality of R\&D personnel. This is probably also due to the proximity of Austria to Eastern Europe. In summary, we can say that internal R\&D is mainly used for knowledge exploiting activities. We can distinguish between market and production support reasons that are realised all over the world. Cost reduction is mainly realised in emerging economies. Austrian firms only use internal R \& D in Western Europe to create new knowledge, which might also be due to path dependency on the one hand (firms started to have production there and later they moved R \& D facilities near to the production plant) and already long-term market perspective on the other hand. Proximity does 
Fig. 4: Share of internal R \& D sites for which the following motives are (very) important according to region

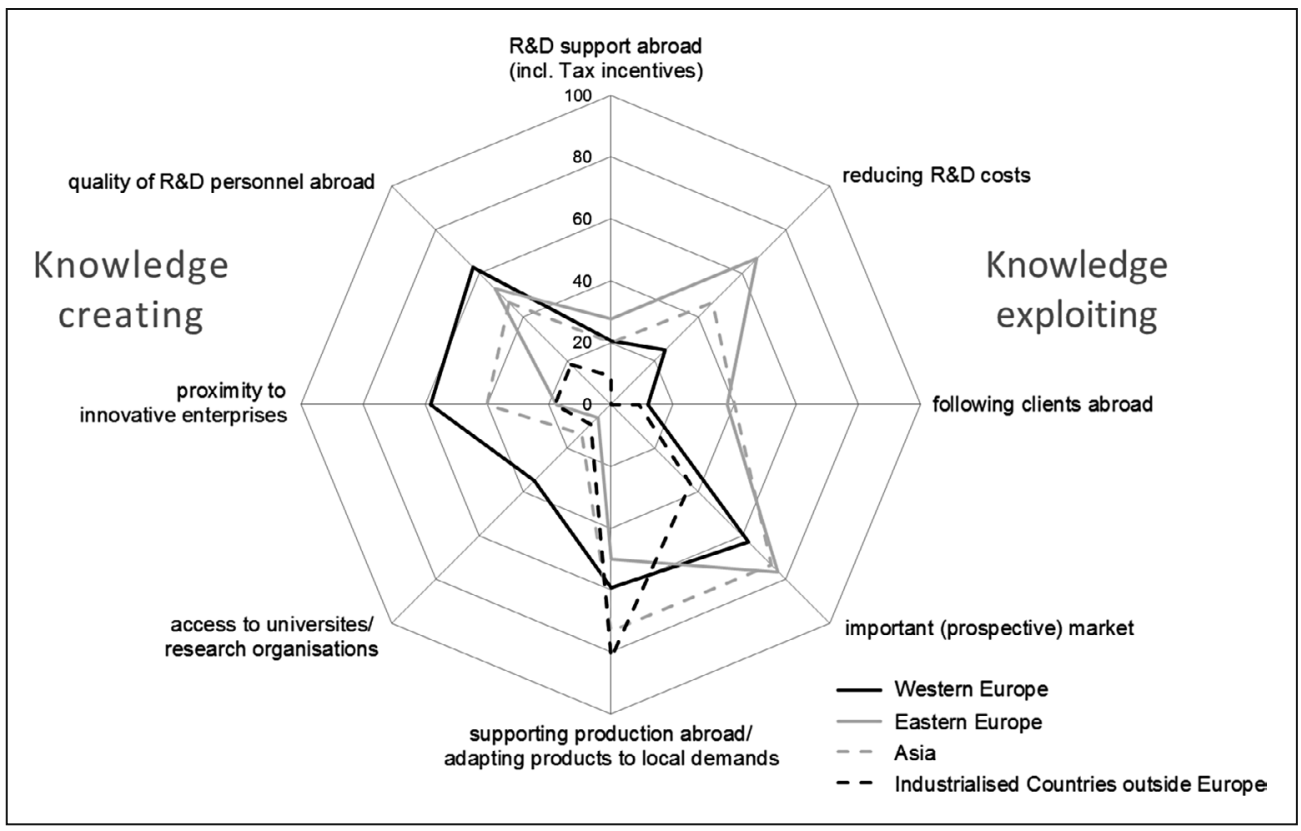

Note: black/grey line: advanced/emerging innovation system; continuous/dashed line: proximate/distant locations Source: Authors' survey and calculations

not seem to matter, internal modes overcome uncertainties and any kind of distance disadvantages.

\section{Cooperative and external $R \& D$ on inter- national level}

In a second step, we analyse the motives according to location for a combined sample of cooperative and external $R \& D$. In total, the sample includes 161 enterprises with 572 R \& D relationships abroad, either cooperative or external; ranging from 1 to 10 partners per enterprise (the questionnaire asked about the max. five most important R \& D cooperation partners and the max. five most important R \& D contractors). Partners for cooperative and external R\&D more frequently are research organisations. Firms profit from the expertise of partners. These external $\mathrm{R} \& \mathrm{D}$ ties with foreign partners are even more concentrated on Europe than internal R \& D sites. This will at least partly be due to the participation in EU-sponsored research projects of the European Framework Programme, which are open for research organisations and enterprises alike.
For about $550 \mathrm{R} \& \mathrm{D}$ partners, the respondents indicated individual motives for collaboration/ contracting (min. 550; max. 556). Fig. 5 presents that knowledge creation motives (expertise of partners, supplementing knowledge) most frequently drive cooperation in Western Europe and industrialised countries outside Europe, and partly in Eastern Europe. In comparison to internal $R \& D$, knowledge creating is not only realised in proximate economies, but also in distant economies. Cost aspects favour R\&D outsourcing and cooperation in emerging economies such as Asia and Eastern Europe. Market arguments are stronger motives for collaboration with remote partners in Asia and North America/Oceania. Efficiency gains in terms of reducing project running time are mainly expected through working with partners in proximity (Western and Eastern Europe) due to better control and coordination mechanisms. In general, proximity and distance plays are larger role in cooperative and external R\&D as they allow for knowledge sharing and creating. If geographical proximity is not given, cultural proximity (see North 
Fig. 5: Share of external/cooperative R \& D partners for which the following motives are (very) important according to region

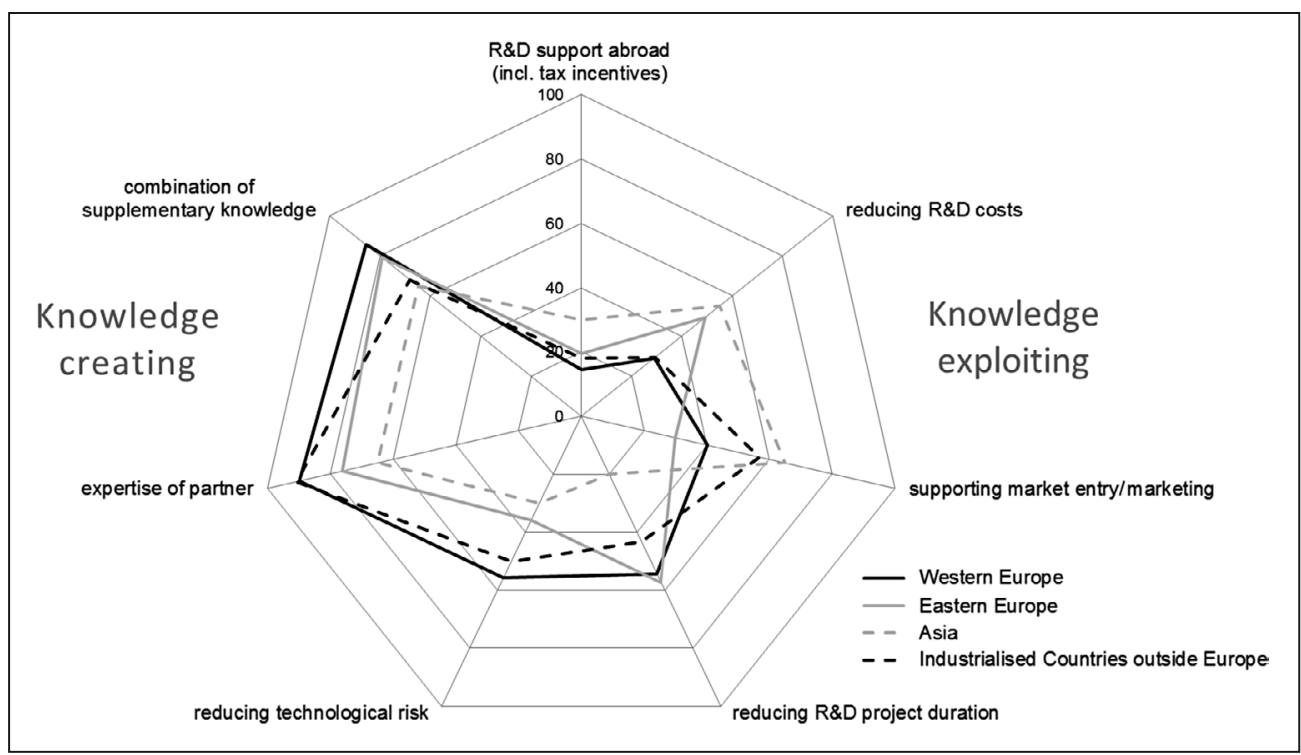

Note: black/grey line: advanced/emerging innovation system; continuous/dashed line: proximate/distant locations

Source: Authors' survey and calculations

America region) can substitute to some extent, but only if the R\&D is driven by the knowledge creating motive.

\section{Future $R \& D$ locations}

Austrian firms were also asked to provide information on their plans to increase or newly generate internal R\&D activities abroad in the next three to five years. The figures show strong inertia of existing patterns (Tab. 4). We made a distinction here between firms with experience in already existing internal $R \& D$ activities abroad and those without. Firms which currently do not have internal R\&D abroad tend to focus on Europe (especially Western Europe), whereas firms that already run their own R \& D facilities abroad have a higher likelihood of setting up R \& D sites in Asia. This may be seen as a clear indication that the internationalisation of $\mathrm{R} \& \mathrm{D}$ is a gradual process in which firms start in regions which are in spatial and/or cultural proximity. Setting up facilities further away (with a more uncertain legal and cultural environment) requires experience. This development obviously depends on size. Larger firms with (more) internal R\&D sites abroad have better knowledge and resource endowment to afford the establishment of further locations in Asia than, for example, micro firms or small firms.

Tab. 4: Planned destinations for internal R \& D

\begin{tabular}{lcrrrrr} 
& \multicolumn{2}{c}{ All } & Firms with internal R\&D abroad & \multicolumn{2}{c}{ Firms without internal R\&D abroad } \\
& $\mathrm{n}$ & $\%$ & $\mathrm{n}$ & $\%$ & $\mathrm{n}$ & $\%$ \\
\hline Western Europe & 77 & $49 \%$ & 29 & $45 \%$ & 48 & $53 \%$ \\
Eastern Europe & 39 & $25 \%$ & 14 & $22 \%$ & 25 & $27 \%$ \\
Asia & 21 & $13 \%$ & 16 & $25 \%$ & 5 & $5 \%$ \\
North America & 11 & $7 \%$ & 4 & $6 \%$ & 7 & $8 \%$ \\
Rest of world & 8 & $5 \%$ & 2 & $4 \%$ & 6 & $6 \%$ \\
\hline
\end{tabular}

Source: Authors' survey and calculations 


\section{Conclusion}

In many countries, SMEs are the backbone of the national economy. Austria as a small economy is in need for competent R\&D partners abroad. Austria delivers evidence how SMEs in Western Europe internationalise R \& D in order to stay competitive. Some studies already hint at the fact that SMEs have started to discover new innovation markets abroad (Economist Intelligence Unit 2011). SMEs in comparison to MNEs face different conditions for the internationalisation process. They have limited financial resources, limited experience abroad and restricted management capabilities. On the other hand, they profit from speed and flexibility, lack of bureaucracy, effective communication and decision making, close customer ties and the opportunity to niche the market. Therefore, SMEs could have their specific strategies and methods of R \& D internationalisation - taken into account that decisions are made under bounded rationality. The purpose of this study is to extend research on the internationalisation of business R\&D while looking into strategic drivers, locational choice and organisational forms of SMEs.

We were able to reveal a specific pattern of strategic drivers that determine the location as well as the organisational choice of international R \& D activities of Austrian SMEs. About half of the Austrian firms surveyed perform international R\&D activities, meaning SMEs are rapidly following MNEs in R \& D internationalisation (Hypothesis 1 can be confirmed). Thereby larger firms have more international $\mathrm{R} \& \mathrm{D}$ than smaller firms. If Austrian firms perform international $\mathrm{R} \& \mathrm{D}$, they prefer an external or cooperative form of $R \& D$ organisation over the establishment of internal R\&D. This is due to the limited financial resources, but also due to the traits of knowledge that allow firms to benefit from more open-access modes (e.g. high value, highly tacit, highly transaction-specific investments). However, it is difficult to assess the relevance of the different $R \& D$ locations for each firm using quantitative analysis. A case study approach would deliver even more insights on international $\mathrm{R} \& \mathrm{D}$ activities (type, location and motive) in comparison to domestic R\&D, especially for SMEs. Moreover, an in-depth analysis gathering information on the markets and production of SMEs would enable an even better assessment of international $\mathrm{R} \& \mathrm{D}$ activities.
Over $70 \%$ of international R\&D activities are located in Western Europe, particularly in Germany, followed by Eastern Europe (14\%). Hypothesis 2 can be confirmed. Only a few activities could be identified in North America and Asia. R\&D activities abroad follow a clear distance decay function. As expected from the theoretical discussion, the main driver for R \& D activities in economies with an advanced national innovation system (such as Western Europe or North America) is knowledge creation. This is true for cooperative and external $R \& D$, but only to some extent for internal R\&D. The open mode of cooperation promises greater knowledge gains and better complementation of knowledge. In contrast, the reduction of $\mathrm{R} \& \mathrm{D}$ costs are mainly realised in emerging economies such as Eastern Europe or Asia (Hypothesis 3 is confirmed).

Distance between the headquarter in Austria and the R\&D location abroad matters only to some extent. If firms source knowledge using cooperative or external modes they prefer proximate to distant economies. The lion's share is located in Western Europe. Cooperative and external modes are distance sensitive and need protection and control which can better be realised in regions of spatial and cultural proximity. Internal $\mathrm{R} \& \mathrm{D}$ activities are more spatially disperse than cooperative or external R\&D activities. There are three explanations for this. Firstly, the serious access to new markets by supporting the production plant to customise products is the main motivation to set up internal R\&D. As markets and production is increasingly organised around the world, these kind of R \& D are as well. Secondly, if locations are spatially distant, uncertainty and transaction costs increase and firms prefer hierarchical structures. Thirdly, internationalisation is a stepwise process. SMEs start to perform R \& D activities in countries within spatial proximity. If they collect sufficient experience on the learning curve, they step forward to more distant economies in terms of space and culture. Locations in distant, but advanced economies (such as North America or Oceania) are already being entered by larger firms, but less often by small firms. Therefore hypothesis 4 can only be confirmed partly, firms prefer proximate economies for R \& D offshoring, but only for specific activities in specific organisational modes. Hypothesis 5 may also only partly be confirmed. Whereas we could show for Austrian SMEs that cooperative and external organisation of R\&D offshoring is preferred in advanced and proximate economies, 
we cannot confirm that internal organisation of $\mathrm{R} \& \mathrm{D}$ offshoring is preferred in emerging and distant economies, but they are realised regardless of where they are in the world as intend to gain new innovation markets.

A future outlook shows that Western Europe will remain the most important location for internal R \& D of Austrian firms in the next three to five years. New facilities and expansions will mainly be concentrated in Eastern and Western Europe. Only firms with existing internal R\&D abroad plan to set up R \& D in Asia. Future activities will be guided by path dependency characterised by strong experience in Western Europe and a stepwise internationalisation and learning process. An interesting continuation of this kind of research would be a longitudinal study to observe temporal changes and developments. Moreover, cross-nation comparisons, e.g. with surveys in Germany, Switzerland and Scandinavia would certainly provide even more insights how SMEs internationalise their R\&D activities.

\section{Notes}

1 Classification of economic activities according to $E u$ rostat - Statistical classification of economic activities NACE Rev. 2.

2 Since the R\&D survey 2007 is classified according to NACE Rev. 1.1, a comparison can only be illustrative.

\section{References}

Ambos, B./Ambos, T. (2011): Meeting the challenge of offshoring R\&D. An examination of firm- and locationspecific factors. In: R\& D Management, (41)2, 107-119.

Bathelt, H. / Malmberg, A. / Maskell, P. (2004): Clusters and knowledge. Local buzz, global pipelines and the process of knowledge creation. In: Progress in Human Geography, (28)1, 31-56.

Belitz, H. (2004): Forschung und Entwicklung in multinationalen Unternehmen. Berlin. (DIW - Deutsches Institut für Wirtschaftsforschung, Studien zum deutschen Innovationssystem Nr. 8-2004).

Bierly, P. / Damanpour, F. / Santoro, M.D. (2009): The application of external knowledge: organizational conditions for exploration and exploitation. In: Journal of Management Studies, (46), 481-509.

BLINDER, A. (2006): Offshoring: the next industrial revolution? In: Foreign Affairs, (85), 113-128.

Boschma, R.A. (2005): Proximity and Innovation. A Critical Assessment. In: Regional Studies, (39)1, 61-74.

CAnTwell, J. (1989): Technological innovation and multinational corporations, Oxford.
Cantwell, J. / Mudambi, R. (2000): The location of MNE $\mathrm{R} \& \mathrm{D}$ activity. The role of investment incentives. In: Management International Review, (40)1, 127-148.

Cantwell, J./Mudambi, R. (2005): MNE competencecreating subsidiary mandates. In: Strategic Management Journal, (26)12, 1109-1128.

Castellani, D. / Zanfei, A. (2004): Choosing international linkage strategies in the electronics industry. The role of multinational experience. Journal of Economic Behavior \& Organization, (53)4, 447-475.

Contractor, F. / Kumar, V. / Kundu, S. / Pedersen, T. (2010): Reconceptualizing the firm in a world of outsourcing and offshoring. The organizational and geographical relocation of high-value company functions. In: Journal of Management Studies, (47)8, 1417-1433.

Demirbag, M. / Glaister, K. (2010): Factors determining offshore location choice for R\&D projects. A comparative study of developed and emerging regions. In: Journal of Management Studies, (47)8, 1534-1560.

DunNING, J.H. (1995): Reappraising the eclectic paradigm in an age of alliance capitalism. In: Journal of International Business Studies, (26)3, 461-491.

DunNing, J.H. (1996): The geographical sources of the competitiveness of firms. Some results of a new survey. In: Transnational Corporations, (5), 1-29.

DunNing, J.H. ( $\left.{ }^{3} 1998\right)$ : Multinational enterprises and the global economy. Wokingham.

DunNing, J.H. / NARUla, R. (1995): The R \& D activities of foreign firms in the United States. In: International Studies of Management and Organization, (25), 39-73.

Economist Intelligence Unit (2011): New horizons: Europe's small and medium-sized companies look to emerging markets for growth. Internet: http://www.economistinsights.com/countries-trade-investment/analysis/new-horizons; 17.3.2014.

Edler, J. / Meyer-Krahmer, F. / Reger, G. (2002): Changes in the strategic management of technology - results of a global benchmarking study. In: R\&D Management, (32)2, 149-164.

FLORIDA, R. (1997): The globalisation of R\&D. Results of a survey of foreign-affiliated R\& D laboratories in the USA. In: Research Policy, (26), 85-103.

GAmmeltoft, P. (2006): Internationalisation of R\&D. Trends, drivers and managerial challenges. In: International Journal of Technology and Globalisation, (2)1-2, 177-199.

Gertler, M. (2003): Tacit knowledge and the economic geography of context, or the undefinable tacitness of being (there). In: Journal of Economic Geography, (3), 75-99.

GLUECKLER, J. (2007): Economic geography and the evolution of networks. In: Journal of Economic Geography, (7)5, 619-634.

Hsuan, J. / MahnKe, V. (2011): Outsourcing R\& D. A review, model, and research agenda. In: R\& D Management, (41) $1,1-7$.

Huggins, R. / Demirbag, M. / Ratcheva, V. I. (2007): Global knowledge and R\&D foreign direct investment flows. Rrecent patterns in Asia Pacific, Europe and North America. In: International Review of Applied Economics, (21), 437-451. 
HymER, S. (1960): The international operations of national firms, A study of foreign direct investment. Boston. (PhD Diss.).

HymER, S. (1976): The international operations of national firms. Cambridge.

Jensen, P. D. O. / Pedersen, T. (2011): The economic geography of offshoring. The fit between activities and local context. In: Journal of Management Studies, (48)2, 352372.

Kuemmerle, W. (1999): The drivers of foreign direct investment into research and development. An empirical investigation. In: Journal of International Business Studies, (30) $1,1-24$.

LEVY, D.L. (2005): Offshoring in the new global political economy. In: Journal of Management Studies, (42), 685693.

Lewin, A. Y. / Massini, S. / Peeters, C. (2009): Why are companies offshoring innovation? The emerging global race for talent. In: Journal of International Business Studies, (40), 901-925.

Malmberg, A. / Maskell, P. (1997): Towards an explanation of regional specialization and industry agglomeration. In: European Planning Studies, (5)1, 25-41.

Manning, S. / Massini, S. / Lewin, A. Y. (2008): A dynamic perspective on next-generation offshoring. The global sourcing of science and engineering talent. In: Academy of Management Perspectives, (22), 35-54.

Martin, R. / Sunley, P. (2006): Path dependence and regional economic evolution. In: Journal of Economic Geography, (6)4, 395-437.

Maskell, P. / Pedersen, T. / Petersen, B. / Dick-Nielsen, J. (2007): Learning paths to offshore outsourcing: from cost reduction to knowledge seeking. In: Industry and Innovation, (14)3, 239-257.

Massini, S. / Miozzo, M. (2012): Outsourcing and offshoring of business services. Challenges to theory, management and geography of innovation. In: Regional Studies, (46)9, 1219-1242.

MeYer, S. (2011): Informal modes of governance in customer producer relations. The electronics industry in the Greater Pearl River Delta (China). Stuttgart. (Megacities and Global, Vol. 1).

MudAmBI, R. (2008): Location, control and innovation in knowledge-intensive industries. In: Journal of Economic Geography, (8)5, 699-725.

Mudambi, S. M. / Tallman, S. (2010): Make, buy or ally? Theoretical perspectives on knowledge process outsourcing through alliances. In: Journal of Management Studies, (47)8, 1434-1456.
OECD (2008): The internationalisation of business R\&D. Evidence, impacts and implications. Paris.

Pearce, R. (2009): Multinationals' strategies and the economic development of small economies. A tale of two transitions. In: Management International Review, (49), 81-94.

Penrose, E. T. (1959): The theory of the growth of the firm. Oxford.

Rovira Nordman, E. / Tolstoy, D. (2011): Technology innovation in internationalising SMEs. In: Industry and Innovation, (18)7, 669-684.

SAXENIAN, A. (2006): The new argonauts. Regional advantage in the global economy. Cambridge, MA.

Serapio, M. / Dalton, D. (1999): Globalization of industrial R\&D. An examination of foreign direct investments in R\&D in the United States. In: Research Policy, (28)3, 303-316.

SimON, H.A. (1991): Bounded rationality and organizational learning. In: Organization Science, (2)1, 125-134.

Statistik Austria (2010): Innovation - Ergebnisse der Sechsten Europäischen Innovationserhebung (CIS 2008). Wien.

STORPER, M. (1995): The resurgence of regional economies ten years later. The region as a nexus of untraded interdependencies. In: European Urban and Regional Studies, (2), 191-221.

Sturgeon, T. / Van Biesebroeck, J./ Gereffi, G. (2008): Value chains, networks and clusters: reframing the global automotive industry. In: Journal of Economic Geography, (8)3, 297-321.

Thursby, J. / Thursby, M. (2006): Here or there? A survey of factors in multinational R\&D location - Report to the Government-University-Industry Research Roundtable. Washington, D. C. Internet: http://books.nap.edu/openbook. php?isbn=0309101840; 17.3.2014.

UNCTAD (United Nations Conference on Trade and Development) (2009): World investment report. Geneva.

WERNERFELT, B. (1984): A resource-based view of the firm. In: Strategic Management Journal, (5)2, 171-180.

Williamson, O.E. (1991): Comparative economic organization. The analysis of discrete structural alternatives. In: Administrative Science Quarterly, (36), 269-296.

ZAHEER, S. / MANRAKHAN, S. (2001): Concentration and dispersion in global industries. Remote electronic access and the location of economic activities. In: Journal of International Business Studies, (32), 667-686.

von Zedtwitz, M./ Gassmann, O. (2002): Market versus technology drive in R\&D internationalization. Four different patterns of managing research and development. In: Research Policy, (31), 569-588. 